\title{
REPRESENTING COLOURS
}

\author{
Lise Bender Jørgensen \\ Department of Historical Studies, NTNU - Norwegian \\ University of Science and Technology
}

\begin{abstract}
How to describe the faded colours in ancient textiles in a way that is understandable to others when no laboratory facilities are available and dye analysis not possible? How do we find names of colours that carry the right connotations to an international readership, and how can we refer to them? The paper discusses challenges posed by these questions and how they have been attempted solved in the Mons Claudianus textile project.
\end{abstract}

Key words: Colours. Colour notation systems. Mons Claudianus. Roman Egypt.

\section{Representar los colores}

Resumen: ¿Cómo describir los colores apagados en los textiles antiguos de una forma que sea comprensible para otros cuando no hay laboratorios disponibles y el análisis del tinte no es posible? ¿Cómo encontramos nombres de colores que lleven las connotaciones adecuadas para los lectores internacionales, y cómo podemos referimos a ellos? El artículo discute los desafíos planteados por estas cuestiones y cómo se han tratado de resolver en el proyecto textil de Mons Claudianus.

Palabras clave: Colores. Cistemas de notación de color. Mons Claudianus. Egipto romano.

\section{INTRODUCTION}

With the PURPUREAE VESTES conferences and conference proceedings, Professor Carmen Alfaro has called attention to the importance of colours and dyes in ancient textiles, the procurement and processing of dyestuffs, how they can be identified in archaeological textiles, and what they meant to people in Antiquity. This has resulted in an important increase in data as well as knowledge about the role of colours and dyes in the Ancient World. Although the main forum for discussing methods of dye identification is the Dyes in History and Archaeology conferences and proceedings, contributions to the PURPUREAE VESTES include papers on thin-layer adsorption chromatography (TCL) and high-performance liquid chromatography (HPLC) (see e.g. Cabrera et al., 2011), as well non-destructive methods such as colour spectrometry that can be carried out by a portable measuring device and a laptop (Paetz gen. Schieck and Fuchs 2011). In recent years, dye analyses of ancient textiles have caused a substantial accumulation of data that now allow us to chart the range of dyestuffs available to dyers in Antiquity and asses how different dyes were combined in order to create specific shades of colour (Cardon et al., 2004).

Data de recepció: 12 de desembre de 2014 / Data d'acceptació: 16 de març de 2015. 


\section{COLOURS IN THE TEXTILES FROM MONS CLAUDIANUS}

Colours are an important aspect of the textiles found at the Roman quarry Mons Claudianus in Egypt that has been the subject for several studies in the PURPUREAE VESTES proceedings (Bender Jørgensen, 2004, 2008, 2011; Ciszuk, 2004, Ciszuk and Hammarlund, 2008). Although the great majority of the many thousands of textiles were made of undyed wool, in a variety of creamy, beige and brown colours, others have been found to be blue, green, pink, purple, red, yellow and even white. In addition, about $13 \%$ of the textiles had decoration in the form of coloured clavi and other bands, or signs such as gammas, etas or iotas (see Bender Jørgensen, 2011 and Mannering, 2000 for definitions). At the time of recording the Mons Claudianus textiles, it was not possible to carry out any form of dye identification. In the beginning, simple adjectives such as 'red', 'blue', 'purple' were used describing colour in a textile, but as work progressed it became clear that this was not sufficient. An important reason for this was that as recorders grew acquainted with Roman colours it was realised that many textiles that first had been designated as 'red' or 'blue' were in fact faded purple. Furthermore, perceptions of colour depend on aspects such as lighting and tend to be subjective. This meant that we needed a reference system for our records that made it possible to designate the colours in a way that made them retrievable for others, i.e. to create scientific references cf. Bruno Latour's concept of circulating reference (Latour, 1999). For this purpose, we decided on the Natural Colour System (NSC), a Scandinavian colour notation system developed to define and communicate exact shades of colour in any material (see http://www.ncscolour.com). Members of the team were familiar with the system that is used by the University of Borås, Swedish School of Textiles. Other notation systems for colours are Munsell (http://munsell.com) that is widely used by archaeologists to describe soil colours (Renfrew and Bahn, 1996, 221), or Pantone (http://www.pantone-colours.com) that is linked to the composition of ink and can be reproduced exactly in print.

\section{THE NATURAL COLOUR SYSTEM}

The Natural Colour system is constructed using properties that visually describe a colour: hue, blackness and chromaticness. Hue designates how similar the colour is to the elementary colours yellow, red, blue and green. Blackness signifies how dark the colour is and chromaticness how chromatically strong it is. The combination of blackness and chromaticness is termed nuance. The NCS system may be perceived as a solid globe where hues form a circle that may be compared to the Equator. Nuances may be seen as vertical slices of the globe, with White in a position comparable to the North Pole and Black to the South Pole (see http://www.ncscolour.com/en/ncs/how-ncs-works/logic-behind-the-system). In this way, 1950 standardised colours have been defined. The elementary colour white is given as W, black as S, yellow as Y, red as R, blue as B and green as G. S1070-Y10R (a strong yellow) is an example of a NCS colour notation. It describes a colour that is included in the standard collection (S) and lies in between yellow (Y) and red (R) colour span with 10\% perceived red (and the remaining 90\% going towards yellow), 10\% perceived Blackness and $70 \%$ perceived chromaticness. Among several products developed by the Natural 


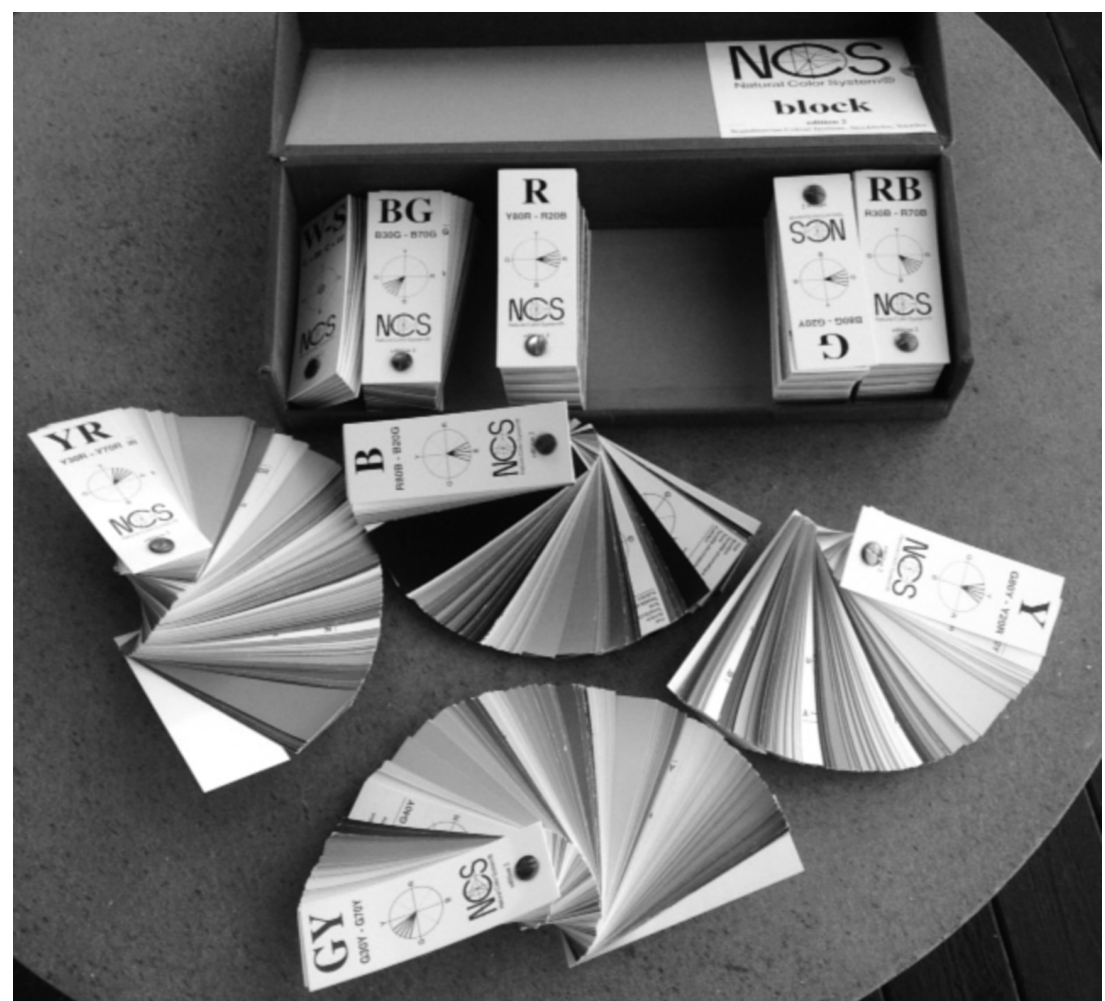

Fig. 1. NCS Block box with fan decks sorted by hue. Photo: Author.

\section{NCS Records}

- Random Sample $\quad$ Selected Sample

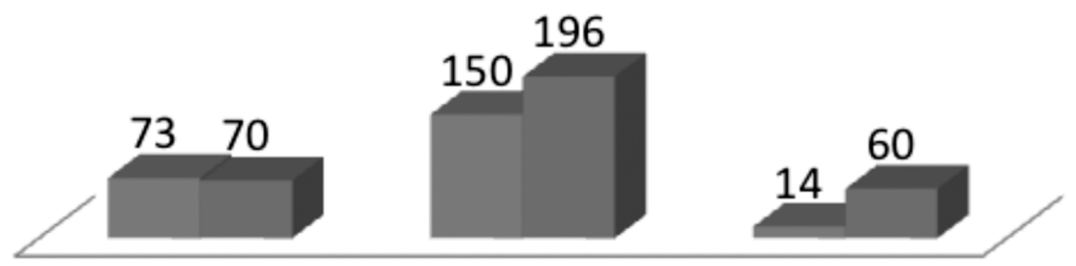

\section{Ground weave Decoration Ground weave and decoration}

Fig. 2. NCS records of the Mons Claudianus textiles. 
Colour System as tools for designers it was decided to acquire the NCS Block, a box with pocket-sized fan decks sorted by hue (Fig. 1). The size was convenient for bringing out to Egypt and comparing with the colours in textiles from Mons Claudianus.

\section{WORKING WITH THE NCS SYSTEM}

All finds from Mons Claudianus, including the textiles, are kept in the stores of the Supreme Council of Antiquities now in Qift, Egypt (see Bender Jørgensen and Mannering, 2001 for details). During the 1998 post-excavation season, the establishment of a set of NCS colour notations was one of the tasks carried out by the textile team. As time was limited, it was not possible to review all the 1826 textiles that had been recorded, so work focused on textiles that had been described as blue, green, purple or red; textiles described as undyed, or in shades of beige, brown, khaki or yellow were not prioritised. This resulted in NCS notations of 563 textiles, i.e. about a third of the recorded textiles. Of these, 237 belonged to the Random sample, 326 to the Selected sample (Bender Jørgensen and Mannering, 2001, 6). This means that colour notations are now available of $18.7 \%$ of the Random sample and $57.8 \%$ of the Selected sample. Records were made of the colour of ground weaves (143 pieces) or decoration (246 pieces), and in 74 pieces where decoration had been applied to a coloured ground weave (Fig. 2). The NCS notations of textiles from the Random sample offer an idea of the relative proportion of colours in the textiles from Mons Claudianus, while those of the Selected sample supply additional information on the range of colours.

It is important to note that although the aim of the exercise was to obtain a form of objectivity in the description of colours, elements of subjectivity were unavoidable. Assessment and recording of NCS notations was carried out outdoors, in the mornings, between about 8.30 and 11 AM (Fig. 3). This was to make colour identifications as homogeneous as possible; as the sun rose, however, the light changed, causing colour perception to change too. Records made early or late within the chosen time frame will to some extent diverge; after 11 AM the light had become so bright that almost everything began to appear brown. The NCS fan decks constituted a further element of subjectivity. Sorted into hues between two colours such as Yellow and Red, Red and Blue or Blue and Green, some of the shades in different fan decks are quite similar. This especially applies to dark brown or grey shades of red, or dark grey shades between blue and green. As time was limited, the first fan deck to produce a colour comparable to the investigated item would tend to be chosen. It means that although the NCS colour notations appear scientifically exact they are not quite so and should be seen as approximate. Their main advantage is that they make it possible to refer to colours in a way that can be transmitted to others.

\section{TRANSLATING NOTATIONS INTO COLOUR TERMS}

NCS colour notations such as 'S7010-B50G' or 'S6020-Y90R' are not immediately understandable to the non-initiated. To visualise the colours that they describe demands considerable practise, and even then offers stumbling blocks. In order to translate the notation codes into an easier format, members of the Mons Claudianus textile team con- 


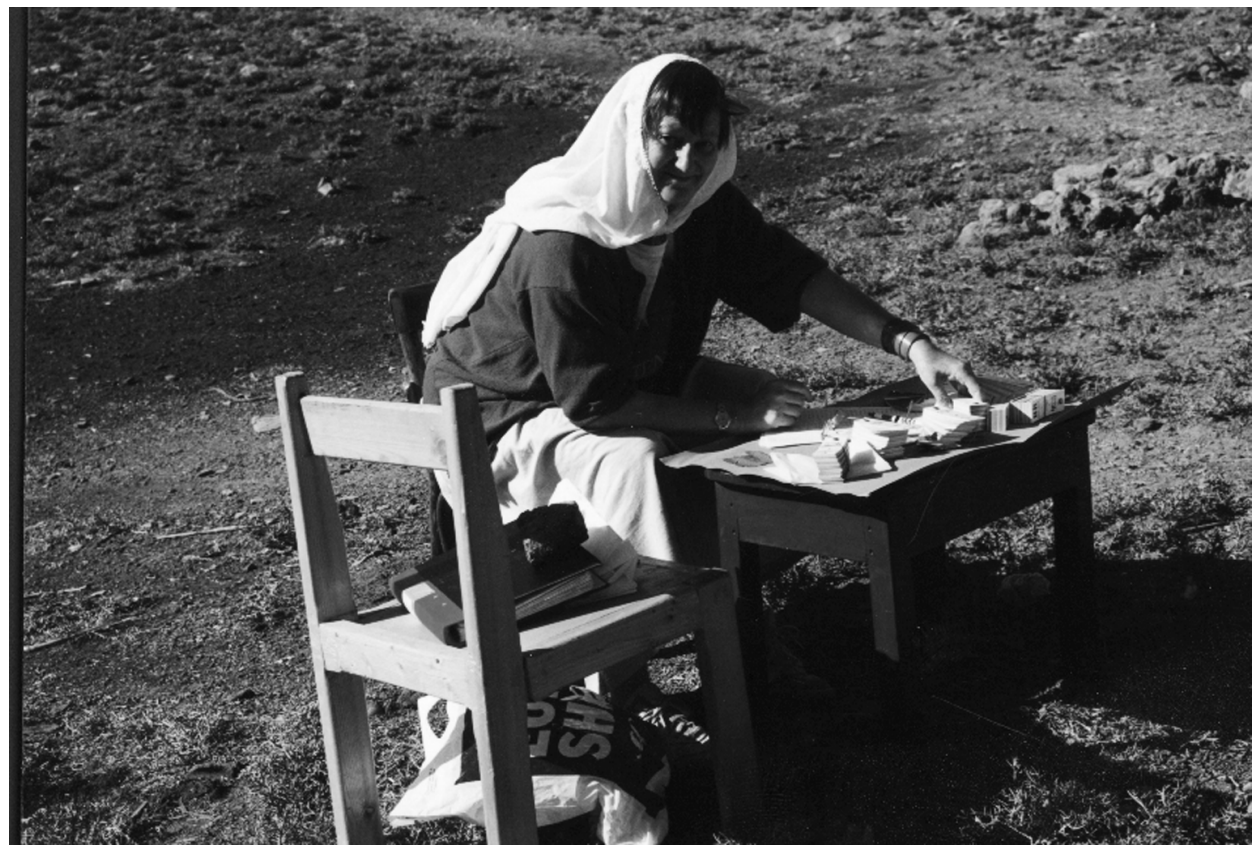

Fig. 3. The author at work in Dendera 1998, comparing colours of Mons Claudianus textiles with NCS fan decks. Photo: J. Bingen.

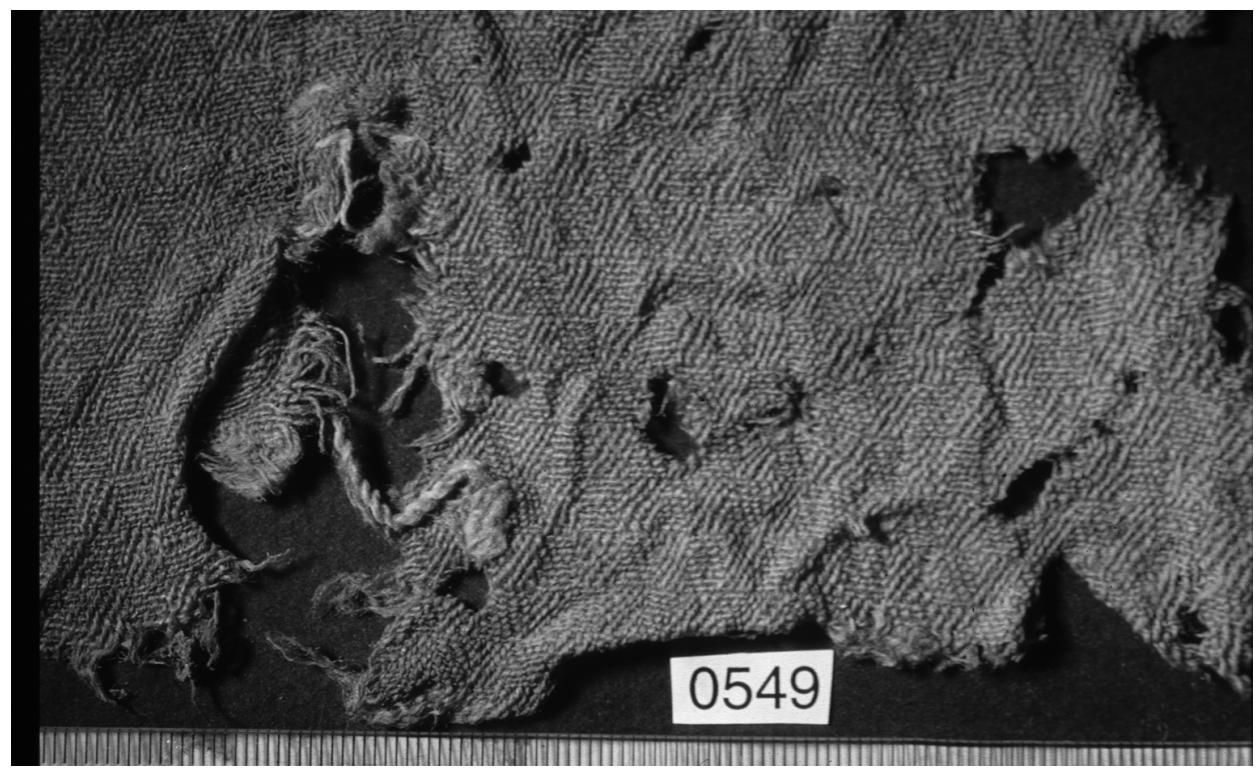

Fig. 4. MC 549, red block damask. NCS S4040-Y80R. Photo: Author. 
structed a set of new colour terms (Viklund, 2007; Mannering, Hammarlund and Ciszuk forthcoming). Notations Y-Y40R were thus defined as Yellowish brown, Y50R-Y70 as Reddish brown, Y80R-R as Red/Reddish brown. R10B-R50B were termed Bluish red, R70B-B20G Blue, and B30G-B40G Bluish green. Records labelled B50G-G30Y became Green, and G50Y-G90Y Yellowish green. S5502 and S7502 are Grey, S9000 Black, and S8010, S8005, S8502 and S8505 Black with a slight colour tone. In addition, these groups of colours are further subdivided into five groups specified with the prefixes: Light - defined by S3030 and S3040 (low blackness and rather low chromaticness); Bright - defined by S3050, S4040, S4050, S5020, S5030, S5040, S6020 and S6030 (most common rather low blackness and rather low chromaticness); Dull - defined by S6005 and S6010 (high blackness and low chromaticness); Dark - defined by S7020 (high blackness and rather low chromaticness); and Dull dark - defined by S7005 and S7010 (high blackness and low chromaticness). Pains were taken to avoid words that carry subjective associations, such as grass green, buff or purple. This system makes it possible to sort the NCS notations into groups that are much more accessible, and offer a means for investigating and discuss the use of colours in the Mons Claudianus textiles in ways that allow scientific reference.

\section{APPLYING COLOUR TERMS}

Using a simple form of the colour terms established this way we find that in the Random sample, 'Red' and 'Reddish brown', i.e. Y50R-R, was common among the coloured ground weaves; these shades were found in slightly over half of the 73 records (Fig. 4). Dark blue and green tints (Bluish black, greenish black, dull dark green, dull dark yellowish green and dull green) are recorded in 23 pieces. Two are light green, seven yellowish brown, while a few pieces had mottled ground weaves (Fig. 5). No less than 17 of the 73 fabrics with coloured ground weave are twills or damasks. These consist of eight reds, six dark blues, one green and two yellowish browns (Fig. 6). Half of the fourteen coloured ground weaves with woven decoration are red with dark blue or green bands or signs (Fig. 7); of the other half, six are shades of green and one a dark blue, decorations in purple or dark red. The decoration of the 150 non-coloured fabrics is mainly in various shades of dark bluish reds or browns; 15 are clear reds, two dark blues, four dull dark greens, and seven have decoration in more than one colour. In the Selected sample, the range of colours is -as to be expected- wider; for ground weaves, green tints are most common, followed by reds and blues; as regards decoration, very dark, almost black shades of blue, red, green and brown make up close to half of the 196 records; 26 are clear reds, 40 are in more than one colour; the rest are dark blues, browns, greens, or greys. Most of these will originally have appeared as purple; the higher frequency of very dark colours suggests that the dyes of textiles in the selected sample had a higher quality.

\section{COLOUR CONNOTATIONS}

Cobalt Blue, Delft Blue, Sky Blue or Ultramarine are names for shades of blue that conveys connotations understandable across languages. Other colour terms are language specific, and are difficult to grasp for people who are not native speakers of the language 


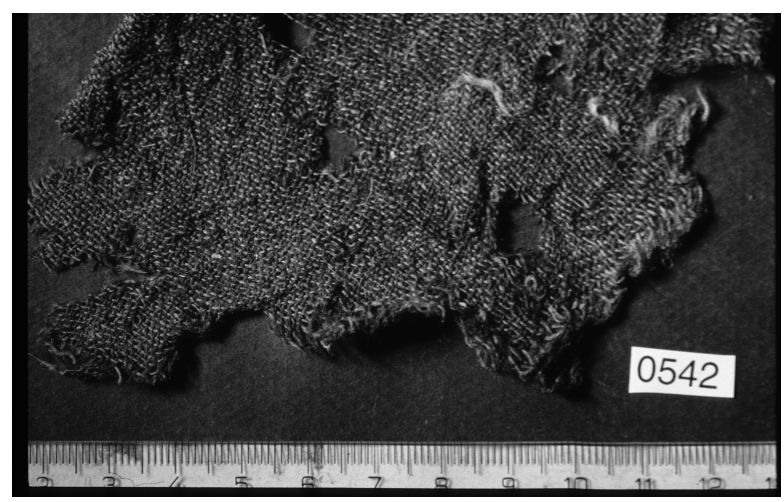

Fig. 5. MC 542. Mottled greenish black tabby. S8010-B90G. Photo: Author.

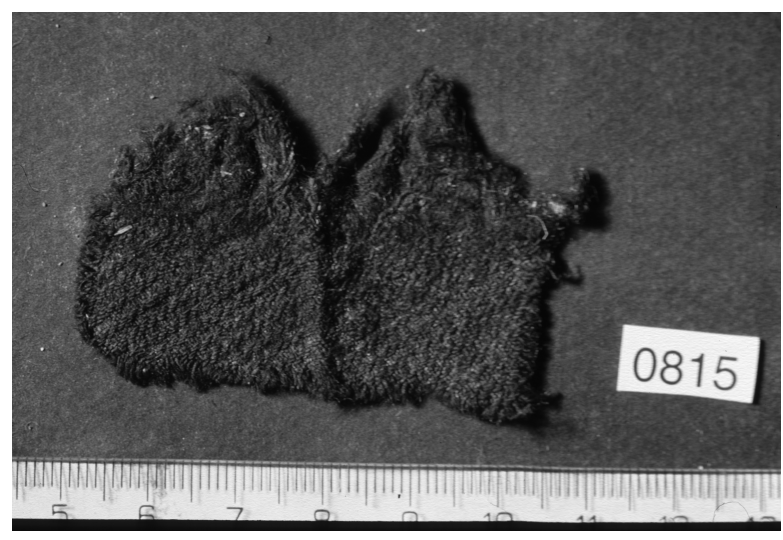

Fig. 6. MC 815. Bluish black barred damask. S8010-R90B. Photo: Author.

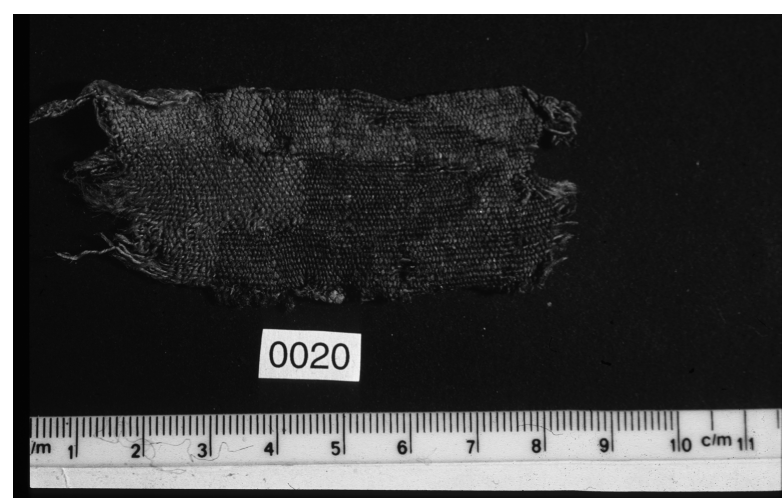

Fig. 7. MC 20. Red tabby S5030-Y80R with dull dark blue sign S7010-B10G. Photo: Author. 
in question. In English, Primrose Yellow or Gunmetal may serve as examples. They are far more evocative than the colour terms chosen by the Mons Claudianus team but were felt to be too subjective and therefore difficult to refer to in scientific terms. It is however not impossible. Artists' colours are used all over the world, and references to them in the form of colour charts are available, e.g. on the Internet (see http://www.pencils.co.uk/en/ $\mathrm{gb} / 4428 /$ artists for an example), and may be worthwhile to explore.

\section{DYES AND COLOURS}

Most studies of colours in ancient textiles have focused on dyes. Dyes are a means to obtain colours in textiles; research has shown that dyers in Antiquity were highly skilled and that the production of fine textiles in all kinds of colours had a very high level of sophistication. The establishment of a dye or combination of dyes in textiles informs us on the colour schemes of Antiquity and on the original colour of individual textiles -it is another way of representing colours.

In their work on dyes from the praesidia of Maximianon, Krokodilô and Didymoi, Cardon et al. (2004) investigated questions such as which method had been used to obtain black, if any of the textiles had been dyed with shellfish purple, and if insect dyes had been used for reds. Samples were taken from textiles described as black or brown black, from textiles ranging between greyish mauve to almost black purple, and from textiles in shades of red ranging from pinks to very dark reds, from orange to crimson (Cardon et al., 2004, 147). They found that three textiles had indeed been dyed with mollusc purple, and that two types of madder (Rubia spp.) had been used not only for the reds, but also in a range of oranges, pinks, purples and blacks, and even for greens when combined with indigotin. Yellow was obtained from Reseda luteola and was combined with madder and indigotin to produce shades of yellow, orange, and green, pink and black (Cardon et al., 2004, 152-153). The colour terms used by Cardon et al. differs from those used by the Mons Claudianus team, but nonetheless -together with colour photographs- indicate close similarities to the colours found at Mons Claudianus. The dark blue strips of ribbed damask from Didymoi (Cardon, Granger-Taylor and Nowik, 2011, Pl. 21d, 22e) are immediately comparable with pieces from Mons Claudianus such as MC 815 (Fig. 6), as are the red diamond twills and block damasks D98.1412.20 and D98.2305.1 (Cardon, Granger-Taylor and Nowik, 2011, PL. 24c-e) and MC 549 (Fig. 4). Among other 'twins' may be mentioned the resist dyed wool tabbies that have been found at Mons Claudianus and some of the praesidia such as Xeron (compare Bender Jørgensen, 2000, Pl. 3 with Cardon, 2011, 20). In some cases, strips and fragments are so alike that they may derive from the same fabric, cut up and turned into items such as kentrones, rag quilts or -blankets, or used as stuffing in pillows (Cardon, Granger-Taylor and Nowik, 2011, 276-277). The praesidia are contemporary with Mons Claudianus; ostraca found at the sites show that there was close connection between the quarry and the praesidia (Cuvigny, 2012), and it is quite likely that the textiles were related too. Resemblances between them are so striking that it appears safe to assume that they were dyed into the same colours, using identical dyestuffs, methods and recipes. This way, the two ways of representing colours come together. 


\section{ACKNOWLEDGEMENTS}

Mons Claudianus textile team members Martin Ciszuk and Lena Hammarlund introduced me to the NCS system; Lena Hammarlund taught me how to use it and assisted in carrying out recording the Mons Claudianus textiles during the 1998 study season. Later, Ciszuk, Hammarlund and Ulla Mannering established the set of colour terms described here. The paper also draws on the MA thesis (hovedfagsoppgave) of Ulla Viklund on the colours of the Mons Claudianus textiles. The late Professor Jean Bingen headed the study session in Dendera in 1998 and skilfully negotiated the transfer of boxes of textiles between the stores in Qift and Dendera with the authorities of the Supreme Council of Antiquities.

\section{BIBLIOGRAPHY}

BENDER JØRGENSEN, L. (2000): "The Mons Claudianus Textile Project”, in: Cardon, D., Feugère, M. (ed.), Archéologie des textiles des origins au Ve siècle. Actes du colloque de Lattes, oct. 1999. Montagnac, Éditions Monique Mergoil, 253-264.

BENDER JøRGENSEN, L. (2004): “Team work on Roman textiles: The Mons Claudianus Textile Project”, in: Alfaro, C., Wild, J.P., Costa, B. (ed.), Purpureae Vestes. Textiles y tintes del Mediterráneo en época romana. Valencia, PUV, 69-76.

BENDER JØRGENSEN, L. (2008): "Self-bands and other subtle patterns in Roman textiles", in: Alfaro, C., Karali, L. (ed.), Purpureae Vestes II. Vestidos, textiles y tintes. Estudios sobre la producción de bienes de consumo en la Antigüedad. Valencia, PUV, 135-142.

BENDER JØRGENSEN, L. (2011): "Clavi and non-clavi: Definitions of various bands on Roman textiles”, in: Alfaro, C., Brun, J.-P., Borgard, Ph., Pierobon Benoit, R. (ed.), Purpureae Vestes III. Textiles y tintes en la ciudad Antigua. Valencia, PUV, 75-82.

BENDER JØRGENSEN, L., MANNERING, U. (2001): "Mons Claudianus: investigating Roman textiles in the desert", in: Walton Rogers, P., Bender Jørgensen, L., Rast-Eicher, A. (ed.), The Roman Textile Industry and its Influence. A Birthday Tribute to John Peter Wild. Oxford: Oxbow Books, 1-11.

CABRERA, A., PARRA, E., RODRÍGUEZ, L., TURELL, L., ARTEAGA, Á. (2011): "Late Antiquity Textiles from Egypt: Dye Analyses of Spanish Collection”, in: Alfaro, C., Brun, J.-P., Borgard, Ph., Pierobon Benoit, R. (ed.), Purpureae Vestes III. Textiles y tintes en la ciudad Antigua. Valencia, PUV, 137-142.

CARDON, D. (2011): "New textile finds from Dios and Xeron, two praesidia of the Eastern Desert of Egypt". Archaeological Textiles Newsletter No. 52, 14-20.

CARDON, D., GRANGER-TAYLOR, H., NOWIK, W. (2011): "What did they look like? Fragments of Clothing Found at Didymoi”: Case Studies, in: Cuvigny, H. (ed.), Didymoi. Une garnison romaine dans le déster Oriental d'Egypte I - les fouilles et le matériel. Le Caire, Institut français d'archéologie orientale, 273-395.

CARDON, D., WOUTERS, J., VANDEN BERGHE, I., RICHARD, G., BRENIAUX, R. (2004): "Dye analyses of selected textiles from Maximianon, Krokodilô and Didymoi (Egypt)", in: Alfaro, C., Wild, J.P., Costa, B. (ed.), Purpureae Vestes. Textiles y tintes del Mediterráneo en época romana, Valencia, PUV, 145-154.

CISZUK, M. (2004): "Taqueté and damask from Mons Claudianus: a discussion of Roman looms for patterned textiles", in: Alfaro, C., Wild, J.P., Costa, B. (ed.), Purpureae Vestes. Textiles y tintes del Mediterráneo en época romana, Valencia, PUV, 107-114. 
CISZUK, M., HAMMARLUND, L. (2008): "Roman looms - a study of craftsmanship and technology in the Mons Claudianus Textile Project", in: Alfaro, C., Karali, L. (ed.), Purpureae Vestes II. Vestidos, textiles y tintes. Estudios sobre la producción de bienes de consume en la Antigüedad. Valencia, PUV, 119-134.

CUVIGNY, H. (2012): "Introduction”, in: Cuvigny, H. (ed.), Didymoi. Une garnison romaine dans le déster Oriental d'Egypte II - Les Textes. Le Caire, Institut français d'archéologie orientale, 1-37.

LATOUR, B. (1999): Pandora's Hope. Essays on the Reality of Science Studies. Cambridge Massachusetts, Harvard University Press, 324 p.

MANNERING, U. (2000): "Roman Garments from Mons Claudianus", in: Cardon, D., Feugère, M. (ed.), Archéologie des textiles des origins au Ve siècle. Montagnac, Éditions Monique Mergoil, 283-290.

MANNERING, U., HAMMARLUND, L., CISZUK, M. (forthcoming), "Colour Identification of the Mons Claudianus Textiles", in: Bender Jørgensen, L. (ed.), Mons Claudianus IV. Textiles. Le Caire, IFAO.

PAETZ gen. SCHIECK, A., FUCHS, R. (2011): "Colour Spectrometry - a non-destructive Method of Dye Analysis applied on Late Roman Textiles from Egypt", in: Alfaro, C., Brun, J.-P., Borgard, Ph., Pierobon Benoit, R. (ed.), Purpureae Vestes III. Textiles y tintes en la ciudad Antigua. Valencia, PUV, 109-118.

RENFREW, C., BAHN, P. (1996): Archaeology. Theories Methods and Practice. Second Edition. London: Thames and Hudson, 608 p.

VIKLUND, U. (2007): Towards a Cosmology of Colours - Roman Textiles from Mons Claudianus. A methodology of approaching meaning of colours in ancient textiles. Unpublished MA thesis, Department of Archaeology and Religious Studies, Norwegian University of Science and Technology, Trondheim. 